\title{
Adaptive Organizational Communication of ASEAN from an Autopoietic Systems Perspective
}

\author{
Dian Christianti ${ }^{1}$ \\ Hermin Indah Wahyuni²
}

\begin{abstract}
This article focuses on ASEAN after the establishment of its community in a systems perspective. The problem elicited in this research is how the ASEAN Secretariat's adaptive communication is able to cope with challenges stemming from the establishment. To answer the question, a case study is applied, using data collection techniques including document analysis, interview, and observation. The findings reveal that ASEAN adaptive communication has allowed the association to grow rapidly to deal with difficulties. It is not, however, as ideal as a system proposed by Luhmann.
\end{abstract}

Keywords: ASEAN Secretariat, ASEAN Community, Adaptive Communication, Structural Change, Coordination Function

1 Student at the Department of Communication Science, Faculty of Social and Political Sciences, Universitas Gadjah Mada, Yogyakarta. Corresponding e-mail: dian.christianty@mail.ugm.ac.id

${ }^{2}$ Lecturer at the Department of Communication Science, Faculty of Social and Political Sciences, and Director of the Center for Southeast Asian Social Studies, Universitas Gadjah Mada, Yogyakarta. Corresponding e-mail: hermin_iw@ugm.ac.id 


\section{Introduction}

The ASEAN Secretariat has entered a new level in its organizational phase through the establishment of the ASEAN Community. As a shared idea among member states, the community was officially declared in December 2015. As conceived, the community consists of three pillars: the ASEAN Economic Community (AEC), ASEAN Socio-Cultural Community (ASCC), and ASEAN Political Security Community (APSC) (ASEAN Secretariat, 2015, p. 2). There have been pros and cons related to the establishment of the community (see Luhulima, 2011; Luhulima, et.al., 2008; Indonesian Foreign Ministry, 2008). However, excluding these issues, it is very interesting to study the association and its community. One thing that should be noted is that the community has gone through a lengthy process before finally being established. The community, therefore, is considered ASEAN's greatest achievement in the thirty years of its existence as well as a mark of the association's development towards a new era (Caballero-Anthony, 2014, p. 563). While ASEAN develops, its secretariat, as the core subsystem of its organization, adapts and adjusts to contemporary developments to maintain its organizational existence.

Since the implementation of the ASEAN Community 2015 policy, many developments have made communication and coordination within and without the Secretariat more complex. These developments will be discussed in this study through the perspective of communication systems and adaptive communication to answer question about the adaptability of the ASEAN Secretariat. The dynamics of the Secretariat development, furthermore, are closely related to ASEAN's development as an organization and the dynamics of the environment outside its system.

According to the researchers' investigation, no research into the association has been conducted using a systems approach that discusses adaptive communication in the ASEAN Secretariat. Most ASEAN-themed research takes an economic or international relations perspective (see Ong, 2008; Caballero-Anthony, 2014; Narine, 2008; Severino Jr., 2008; Kraft, 2000). Only a few studies use a communication science perspective to examine ASEAN. The difficulty of finding organizational and communication studies about ASEAN is shown through a survey of journals discussing Southeast Asian studies. As such, field research is necessary to collect related information. Furthermore, the researchers have not found other studies of adaptive communication in the ASEAN Secretariat that use a systems theory approach. It can 
therefore be concluded that this research is one of the first studies about the ASEAN Secretariat that uses a communication systems perspective. This research is expected to provide a new perspective in the rife of ASEAN studies using economic and international relations perspectives.

This study is important because the significant development of ASEAN has been closely related to the organization's effort to adapt with the world's challenges and changes. By using a systems approach and adaptive communication analysis, the association as an organization is seen from its ability to identify its own characteristics and capacity; therefore, it can be assumed that the study give new perspective and insight about ASEAN from a systems perspective. Such a perspective is used in this study because using a systems approach tends to be unpopular among and considered unimportant by certain parties. The use of a systems approach is expected to give a holistic and broad view of a problem, in this case the ASEAN organization. Luhmann (2013, p. 121), a philosopher in systems theory, states that a system attempts to reduce complexity within its environment and replicate inside its body to maintain its existence. Therefore, a system will also represent the complexity of its environment. This is the place for adaptive communication. When the environment becomes more complex, the system inside will also adapt using the same mechanisms to adjust and maintain its existence.

Communication by a system done in response to certain demands from its environment is called adaptive communication. Conducting a study of ASEAN, as described above, is important because of the complexity of the organizational condition and environment in which its system is located. Recognizing such environmental conditions, the association must continue adapting to changes. The association faces many demands, and therefore its adaptive communication will determine how it will grow and develop. If ASEAN fails to communicate itself in answering the demands of its environment, it can be smothered by its own problems. Herein lays the importance of adaptive communication: without it, the association will not be able to resolve its problems and will be perceived as underdeveloped, thus leading to entropy.

This study describes the communication system in ASEAN, with emphasis on adaptive communications and values affecting the adaptive organization. Why, then, does this study focus on the adaptive communications of the ASEAN Secretariat? In 
Luhmann's theory, every system with adaptive capabilities is assumed to have the ability to extract information from its surroundings and to use said information for adaptive benefits-similar to how ASEAN has demonstrated significant changes, especially after ASEAN Community policy was implemented in 2015. What makes ASEAN unique among other regional organizations is the principles of noninterference and intergovernmentalism that are stipulated in the Charter, its institutional framework. It is undeniable that the organization is highly dynamic in its responses to the vigorous dynamics of its environment. Therefore, the organization's communications in response to the changing environment will be explored here.

\section{Literature Review}

In social studies, systems theory is an approach that is greatly affected by areas of contact between the natural and social sciences. Similar to how biology sees cells and organisms, some social scientists also try to explain to the public using a systems approach. Biology's study of organisms consisting of smaller composers that unite in a system has inspired social experts to explain the state of society in the same way.

Sociology sees society as a large circle in which there are other small circles with different functions. Each 'circle' is part of the great circle. Among those small circles, there is a power called interdependence. Just like the cells that make up an organism, systems within society affect and depend on each other to form a social system. The social systems approach, based on this systems theory, also includes an explanation of organizations, as organizations are also categorized as social systems (Koskinen, 2013, p. 63). General system theory based on biology was first proposed by Ludwig von Bertalanffy (Miller, 2012, p. 59). Basically, this systems theory divides systems into three elements; system components, system processes, and system properties. System components refer to the parts contained in a system or object. When viewed from the most basic standpoint, a system consists of smaller parts that work together and are interconnected. System properties cover hierarchical arrangement, interdependency, and permeability, that is, the ability to allow information to enter or leave a system. 


\section{Information Systems Approach to Organizations}

According to this theory, an organization is not viewed as a living organism like it used to be, but rather as a result of information processing. Karl Weick, the founder of this theory, put forward a clear distinction between equivocality and uncertainty resulting from information processing (Griffin et al., 2014). Equivocality is a condition in which information processing produces two or more alternatives but no longer requires additional information. Uncertainty, on the other hand, is a condition in which there is a shortage of information. Information processing, furthermore, is called sense making. To be able to do sense making, an organization needs requisite variety, a match between the existing data and the occurred equivocality. How does a loose-coupled organization cope with changing environments and massive amounts of information? This is the role of sense making and requisite variety.

Weick, in addition, introduced three stages of organization evolution (Griffin et al., 2014). The first stage is the enactment or creation/formation. Enactment in this theory means the initiative of the organization to create its own environment. A company, for example, points to those that will be their stakeholders, decides how far the media can cover news about the company, etc. The second stage is selection, which is conducted because of equivocality generated by the first stage. The next stage is retention or repetition. In this stage, the system tries to 'memorize' the results of the selection made and to repeat it so that it becomes a standard pattern. When the selection results in the same continuous retention, it will reduce the flexibility of an organization in responding to complex information (Griffin et al., 2014).

\section{Luhman's System Theory}

Niklas Luhmann developed a systems theory that combines Talcott Parson's structural functionalism with general systems theory and outlined some different concepts. His most famous systems theory concepts are autopoiesis, differentiation, self-reference, and double contingency. These four concepts are a consequence of Luhmann's approach, which sees each system as having different conditions and needs. The key to Luhmann's thought is the assumption that a system is different from its environment, which has greater complexity. A system should be able to develop a new subsystem to adapt to its environment. Luhmann's understanding of systems, therefore, is very similar to the depiction of cells in living organisms, which likewise 
are very dynamic in nature and have the automatic capability to adapt to their environment.

The difference between general systems theory and Luhmann's systems theory is the assumption that adapting systems are simultaneously closed and open (Luhmann, 2013, p. 64). Systems have the capacity for autopoiesis, to produce their own basic elements. Luhmann (2013, p. 43) also offers the concept of self-reference, which is considered very important in explaining the differences between systems and environments. Unlike the system boundaries offered by Parson, open systems do not have a clear distinction with their environment. Therefore, Luhmann (2013, p. 46) puts forward the concept of self-reference to explain how systems distinguishes themselves from their environments.

For Luhmann, when a system is not capable of self-reference, it fails as a system that acts as "itself" (Ritzer, 2003, p. 242). The interesting point in Luhmann's system theory is the way systems perform self-reference, that is, through communication (Luhmann, 2013, p. 53). In his theory, Luhmann emphasizes the importance of communication for social systems (Ramage \& Shipp, 2009, p. 211) as the basis for adaptive communication.

Considering the concepts of autopoiesis and self-reference, Luhmann's systems theory considers complexity part of systems. In his book, Luhmann (2013, p. 125) explains that complexity exists both in the environment and the system. They are mutually influential. Basically, a system will produce certain complexity in response to its environment's complexity. However, it is unlikely to be more complex than its environment.

This understanding is based on the concept of "reduction of complexity", in which systems make formulations within themselves to reduce environmental complexity (Luhmann, 2013, p. 121). Luhmann argues that the concept of complexity can be considered in two ways, namely 'elements' and 'relations' (Luhmann, 2013, p. 124). The more elements possessed by a system, the more relationships contained within it. At that point, the system is considered to be complex. The complexity of a system will affect its communications, which will create disproportion due to the increasing number of elements and relationships within the system.

Communication forms change to become more hierarchical as a result of complex systems. This can be seen from the differences between a large enterprise 
and a group of ten people. In a large enterprise, communication does not occur at the individual level, but at the division level. In a group of ten people, however, communication can involve each member. Within a large enterprise, therefore, communication is done hierarchically to avoid ineffective communication. The idea that 'everything is connected with everything' is impossible in a complex system (Luhmann, 2013, p. 125).

Adaptive communication, basically, is an emerging concept based on Luhmann's systems theory about autopoiesis and complexity. Drawing on Luhmann's concepts, explained above, adaptive communication has emerged as a way for systems to respond to their environments. In Luhmann's systems theory, the essence of a social system is communication, which negates human function (Luhmann, 2013, p. 53). Communication terms, therefore, are used to describe systems' tendencies in duplicating their environment's complexity.

Luhmann's systems theory, especially the concept of adaptive communication, does offer an abstract concept. As expressed by Pace and Faules (2010), the systems theory of Luhmann (2010, p. 67) serves to create an abstract concept for organizing thoughts and directing them to a particular goal. An example of this is the food transportation system in trees. The roots obtain water and how the water flows to leaves through plant's capillaries. Then, the water is used for photosynthesis and the products are sent back to all parts of the plant through the capillaries. These concepts cannot be seen. One cannot see how water flows through the capillaries or the process of photosynthesis. However, these things serve to provide an understanding of a tree's function in sending food so that its growth can be better realized.

\section{Research Method}

The method used in this study is a qualitative approach using a case study method, in which a study serves to describe an event or object as a unique case. According to Yin (2009, p. 18), the case study method is an empirical study to investigate a phenomenon in depth without relinquishing the social context. The study, in addition, has the novelty of the approach and the theory used, namely systems theory. The modern systems theory by Niklas Luhmann in particular is expected to provide unique value in this study. 
Data collection techniques used in this study are document analysis, interviews, and direct observation. The search of archival records has provided data that includes the opinions and statements of ASEAN officials. Document analysis was selected because much of the association's important information is stored in the form of documents, be they agreements, charters, etc. Selected documents were obtained either from the official website or from the ASEAN Resources Center at the ASEAN Secretariat. Interviews were conducted with expert sources, both academics and practitioners in the ASEAN field. Data were also obtained through direct observation of activities; this was done to understand the facts or natural setting in ASEAN as an organization.

\section{Research Findings}

Based on the theory described earlier, development in ASEAN is triggered by changes and challenges arising in the environment. The ASEAN Secretariat, as the main institution in the association, follows its developments in order to respond to those challenges. Over time, it has been inevitable that an international organization should meet the challenges arising from technological developments. These challenges require the Secretariat to adapt to maintain its existence. Otherwise, the ASEAN system will not be able to survive and will be eroded by the challenges faced.

\section{ASEAN and Globalization}

According to the "Dictionary of the Social Sciences" (2002, p. 192), globalization is a term used to describe political, economic, and cultural activities beyond national borders. In Southeast Asia, globalization began before the 1990s and has become more rapid after the end of the Cold War (Wuryandari, 2011, p. 12). Globalization in Southeast Asia has led to another phenomenon, namely faster and easier interaction between individuals and corporations. This has, in turn, affected on the economies, politics, and cultural dimensions of ASEAN member states. Citizens of Malaysia, for example, can communicate easily with citizens of Brunei Darussalam by using the internet and various other cultural exchanges. Meanwhile, in industry, a foreign company can establish production bases in countries with lower production costs, such as Vietnam. This has exceeded the boundaries of conventional state, which used to be one of the obstacles blocking cross-country interaction in the community. 
Globalization has had many effects, both positive and negative (Wuryandari, 2011, p. 72). This is an unavoidable part of the economic globalization trend. Today, a country's economy tends to have a dependency with other countries, as well as the easy mobility of labor, investment, and capital. The dynamic environment of globalization has also pushed ASEAN to transform. In the 1990s, the association expanded, with four new member states being admitted: Vietnam (1995), Laos and Myanmar (1997), and Cambodia (1999). Thus, the ten members of ASEAN are now Singapore, Malaysia, Indonesia, Thailand, Philippines, and Brunei Darussalam (known as the ASEAN 6), and Cambodia, Laos, Vietnam and Myanmar (also known as CLMV). At the same time, the rhetoric of "One Southeast Asia"-intended to create a safe, peaceful, and prosperous area-also appeared (Ba, 2009, p. 105).

Many questions have arisen about CLMV countries' incorporation in ASEAN and the problems that have occurred since; however, ASEAN has proven that it is capable of surviving despite conflict. This, however, does not mean that there will be no conflict or other friction in the future, given the differences in Southeast Asian countries (Ba, 2009, p. 120). To face the possibility of disintegration in the future, ASEAN has taken various anticipatory steps to bring the association into a more integrated new era. One of these is the politics and rhetoric of "One ASEAN", which was translated into institutional restructuring and the making of new agreements or specific amendments. To renew the Bangkok Declaration, ASEAN's leaders have also enacted the ASEAN Charter, which serves as the organization's institutional foundation.

As a regional organization, ASEAN has made a relatively good impression, particularly in facing globalization. The association has also been regarded as the most successful regional organization after the European Union (Weatherbee, 2009, p. 91). Although the EU and ASEAN have different ways of organizing and running their organizational mechanisms, it is nevertheless undeniable that globalization has had a great impact on the politics, economies, and culture of both regional organizations and on other countries in the world. It has significantly changed the face of these two organizations.

In the context of economics, according to the book ASEAN 2030: Toward a Borderless Economic Community (ASEAN Secretariat, 2014, p. 13), economic development in Asia, including ASEAN, was affected by the 2008-2009 recession 
experienced by the United States, which later spread to other countries. This is one weakness of integrated economic policy and international trade in which a country has dependency with other countries. If one of these countries' economies collapses, it will affect the economies of other countries. In this case, the United States had poor credit with high levels of consumption, whereas people could not pay their bills (Wuryandari, 2011, p. 73). High consumption levels were also triggered by low mortgage interest rates and a variety of lures tempting people to use credit. As a result, an economic bubble emerged when consumers' were unable to pay the bills. These economic problems did not only affect the United States, but also financial institutions in Europe and the Americas. As mentioned above, this is caused by the connection among such financial institution networks, which have become interdependent with one another.

Despite the economic problems caused by interdependence, the economic crisis in the United States and other countries in 2008 had a positive impact on the economy in Asia. As a result of financial paralysis in the United States and Europe, the flow of money began to shift to Asia and resulted in the expansion of business. The value of the Chinese Yuan began to rise against the US dollar and trade in China and India increased. The crisis thus had enhanced regional competitiveness in Asia, and the shaft of ASEAN cooperation began to turn to Asian countries such as China, Japan, and India.

In the context of the Asian region, China's economic growth began to encourage trade and investment from the country to ASEAN countries. This, of course, led to intense competition between China and Japan, which had first penetrated the ASEAN market. Japanese companies in ASEAN, therefore, have had to increase performance efficiency to boost productivity in the face of annual increases in the value of trade and investment between China and ASEAN. It is projected that the ASEAN's economy will experience high growth in the future, and there is the possibility of other countries investing in the region.

China's desire to become a superpower is one example of multi-polarity in postCold War international politics (Wuryandari, 2011, p. 8). With the world axis shifting to China, it is expected that ASEAN can take advantage of this momentum effectively. Liberalization and trade integration in the association could create a larger market and allow it to compete with major countries in the world (Ba, 2009, p. 137). However, 
the liberalization of trade in ASEAN would bring new challenges. Correct economic policies are necessary to ensure positive results for the association.

To address economic challenges, ASEAN is currently focusing on the agenda of its community, one pillar of which is the ASEAN Economic Community (AEC). Economic development has become a hot issue in many parts of the world, including Southeast Asia. Through the ASEAN Economic Community, Southeast Asian countries, most of which are developing countries, are hoped to become a world economic power equal to well-developed countries such as the United States, China, Japan, and the EU. To keep pace with economic lag, ASEAN cooperates with these countries while reinforcing regional integration through the AEC "ASEAN 2030: Toward a Borderless Economic Community" (ASEAN Secretariat, 2014, p. 3). In addition, in 2030, ASEAN is projected to be a region without borders between countries in economic terms. This may involve a single market and a single currency or a common currency. The question is whether the association will be able to achieve this vision by 2030 .

A book titled ASEAN 2030: Toward a Borderless Economic Community elaborates ASEAN's vision for 2030 and how it will be achieved. As a starting point, this book provides an overview of how ASEAN should distinguish itself from the EU. Economic cooperation and integration in ASEAN should not duplicate that in the EU. Instead, the association should set points of cooperation that are in accordance with its own values. More robust cooperation can be achieved, though care should be taken to avoid too fast and high economic growth, which may cause various social problems and political tensions (ASEAN Secretariat, 2014, p. 4). Steps should be taken by ASEAN through appropriate policies, such as reforming the governance principles to keep pace with the world economy, politics, and society. Establishing new institutions is also necessary to implement ASEAN's policies. However, both of these solutions require much time to be fully implemented by ASEAN's members and to take root. The establishment of new institutions at a given point, in addition, can lead to potential complexities within the ASEAN policy system itself.

\section{Development of ASEAN and ASEAN Community}

The ASEAN Vision and ASEAN Charter became the main foundation for ASEAN development in the 2000s, as the association entered its fourth decade. With the vision and charter, ASEAN has more clearly entered a new phase towards realizing the 
ASEAN Community. Here are policy adaptations made by ASEAN with regard to the ASEAN Community:

Table 1. List of ASEAN Agreements in ASEAN Community Framework

\begin{tabular}{|c|c|}
\hline Year & Treaty \\
\hline 1997 & ASEAN Vision \\
\hline 1998 & Hanoi Plan of Action \\
\hline 2003 & Bali Concord II \\
\hline 2007 & Kuala Lumpur Declaration \\
\hline \multirow[t]{2}{*}{2009} & $\begin{array}{l}\text { Cha-am Hua Declaration on the Roadmap of ASEAN Community } \\
(2009-2015), 1 \text { March } 2009\end{array}$ \\
\hline & $\begin{array}{l}\text { Cha-am Hua Declaration on Intergovernmental Commission on Human } \\
\text { Rights, } 23 \text { October } 2009\end{array}$ \\
\hline 2010 & $\begin{array}{l}\text { Hanoi Declaration on the Adoption of ASEAN Connectivity, } 28 \text { October } \\
2010\end{array}$ \\
\hline 2011 & Bali Concord III, 17 November 2011 \\
\hline \multirow[t]{2}{*}{2012} & ASEAN Human Rights Declaration, 18 November 2012 \\
\hline & $\begin{array}{l}\text { Phnom Penh Declaration on ASEAN: One Community, One Destiny, 3-4 } \\
\text { April } 2012\end{array}$ \\
\hline 2013 & $\begin{array}{l}\text { Bandar Seri Begawan Declaration on the ASEAN Community Post-2015 } \\
\text { Vision, } 9 \text { October } 2015\end{array}$ \\
\hline \multirow[t]{2}{*}{2014} & $\begin{array}{l}\text { Nay Pyi Taw Declaration on Realisation of ASEAN Community by 2015, } \\
11 \text { May } 2014\end{array}$ \\
\hline & $\begin{array}{l}\text { Nay Pyi Taw Declaration on the ASEAN Community Post-2015 Vision, } \\
12 \text { November } 2014\end{array}$ \\
\hline \multirow[t]{3}{*}{2015} & $\begin{array}{l}\text { Kuala Lumpur Declaration on a People-oriented, people-centered } \\
\text { ASEAN, } 27 \text { April } 2015\end{array}$ \\
\hline & $\begin{array}{l}\text { Kuala Lumpur Declaration on the Establishment of the ASEAN } \\
\text { Community, } 22 \text { November } 2015\end{array}$ \\
\hline & Kuala Lumpur Declaration on ASEAN 2025: Forging Ahead Together \\
\hline 2016 & $\begin{array}{l}\text { Vientiane Declaration on the Adoption of the Initiatives for ASEAN } \\
\text { Integration (IAI) Work Plan III, } 6 \text { September } 2016\end{array}$ \\
\hline
\end{tabular}

(Source: ASEAN Document Series 1997/1998-2015/2016)

On the agreement table, we can see ASEAN's dynamic development in realizing the Community. Between the first agreement in 1998 and the drafting of the final blueprint in 2008 (Bali Concord II), ASEAN continued to develop to manifest the establishment of the Community. Agreements, however, did not only engage the ASEAN pillars, but also involved other areas supporting the realization of the ASEAN Community, such as human rights (see the agreements in 2009 and 2012). After its community was officially implemented in December 2015, ASEAN formulated policies for the future (see the agreements in 2013-2015). This demonstrates ASEAN's dynamic development to face challenges and to see how the association maintains its 
existence. Additionally, the Secretariat has responded to environmental challenges by adapting its structure through policies at the ASEAN level.

Table 2. Structure Changes of ASEAN Secretariat since 1992

\begin{tabular}{ll}
\hline $\mathbf{1 9 9 2}$ & Changes \\
& $\begin{array}{l}\text { Structure consisted of four directorates, ten director assistants, and an } \\
\text { ASEAN Cooperation Unit. }\end{array}$ \\
\hline $\mathbf{2 0 1 2}$ & $\begin{array}{l}\text { General Secretary Deputy structure was removed and replaced by four } \\
\text { divisions. The name "directorate" was changed to "department"; } \\
\text { "director assistant" was changed to "division"; department naming was } \\
\text { adjusted with AC pillars; and "General Affairs" was renamed "Corporate } \\
\text { and Community Affairs". Total division addition: } 37 \text { divisions. }\end{array}$ \\
\hline $\mathbf{2 0 1 6}$ & $\begin{array}{l}\text { Strategic Planning and Coordination division removal. Total division } \\
\text { addition: } 57 \text { divisions, mostly in the Economic Community Department. }\end{array}$ \\
\hline
\end{tabular}

(Source: ASEAN Secretariat Structure in 1992, 2012, and 2016) ${ }^{3}$

Observing the changes above, it is apparent that the structure of the ASEAN Secretariat is adaptable in the face of environmental challenges. This can be seen in the division, addition, or subtraction of the structure to meet environmental demands and challenges and thus adjust to changes over time. The considerable time span between the first and second amendment is particularly interesting to notice. In the first structural change, it took 20 years for ASEAN to replace its structure. Meanwhile, the distance between the second and the third structural changes is only about four years (2012 and 2016). This difference cannot be separated from the history and the condition of each era, when ASEAN 'woke up' after the economic crisis of 1997-1998. Since then, the association attempted to organize its institution until finally, in 2012, structural changes to support contemporary and future ASEAN activities was approved.

\footnotetext{
${ }^{3}$ The structure of the ASEAN Secretariat in 1992 can be seen in Selayang Pandang ASEAN tahun 1987 (available from the ASEAN Resource Center, ASEAN Secretatriat, Jakarta). The structure in 2012 was derived from website www.asean.org in 2015. Presently, the structure of the ASEAN Secretariat on the website has been changed to the 2016 structure.
} 


\section{Inter-Institutional Relations in ASEAN}

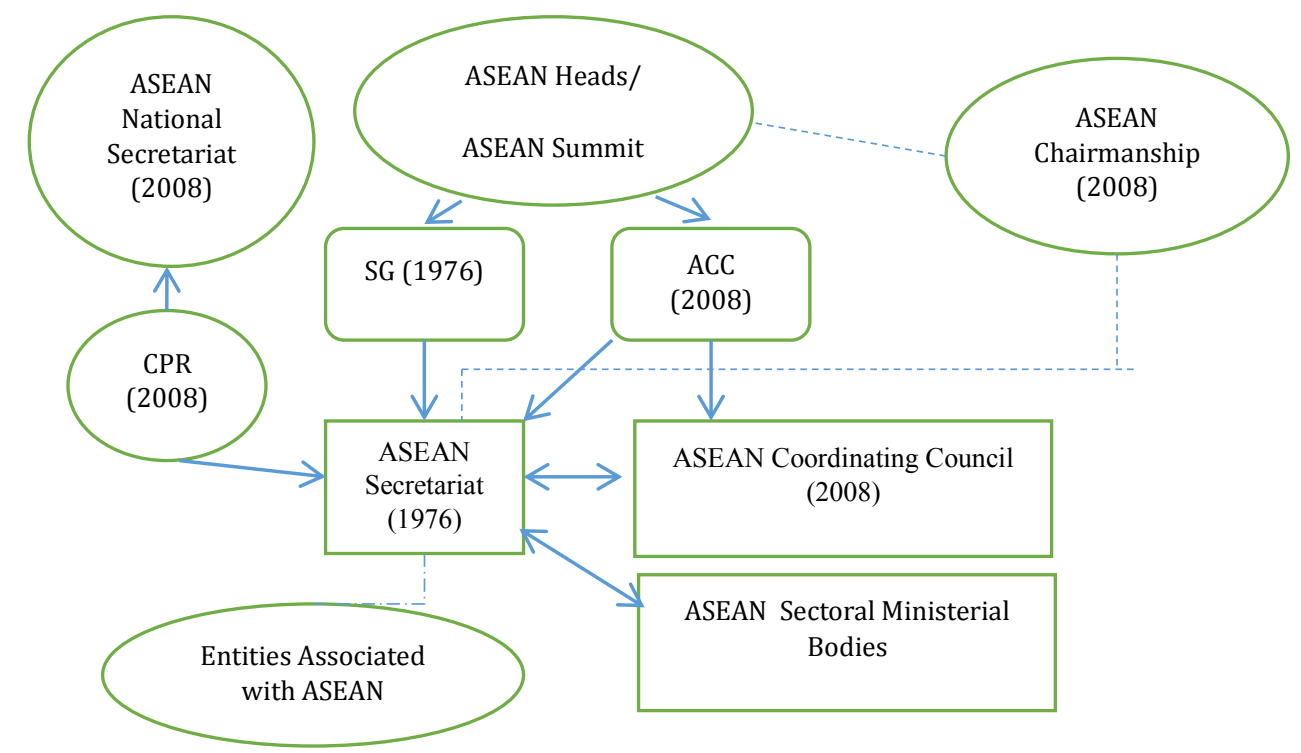

Figure 2. A diagram of inter-institutional relations in ASEAN (Source: Indonesian Foreign Ministry 2008)

Adaptive communication by the ASEAN Secretariat is also illustrated through the relationships among institutions in the association. The above diagram is the simplified version $^{4}$ of the inter-institutional relations in ASEAN. The difficulty in mapping systems in the organization emerges because there are many bodies or institutions, resulting in each system having extreme complexity. From the above diagram, the system in ASEAN can be surmised to consist of three main systems: the elite system, technical system, and institutional system affiliated with the association. Each year, new institutions are established, adding to complexity in the organization. Anytime a new institution is added to the association, relations within it also increase. Inter-institutional relationships in ASEAN, therefore, are adaptive to environmental changes.

\footnotetext{
${ }^{4}$ The existing structure in ASEAN is more complex and needs further investigation to map its overall function and inter-institutional relations in ASEAN. The diagram above is meant to provide a general depiction of the main institutional relations in ASEAN and its connection to the association's activities.
} 


\section{Events/Programs in ASEAN}

Every year, new activities and programs tailored to the needs of the association and stakeholders (communities, governments and other international organizations that work with ASEAN) are proposed. The organization can be quite adaptive to environmental changes in terms of activities and programs. Based on the annual report of the ASEAN Secretariat, every year a significant increase in the number of meetings is also recorded due to the addition of institutions and policies.

\section{Discussion}

From the findings above, the evolution of ASEAN can be divided into several stages. The first is the embryo stage, in which the association had been established based on the Bangkok Declaration of 1967 but lacked any formal institutions or governance mechanisms. The second stage is the genesis or early stage, in which the association began forming institutions that became the basis for its future, namely the establishment of the ASEAN Secretariat. However, at that time, it had neither a special function nor an institutionalized assignment. The third stage is the increase from five ASEAN member states to ten with the joining of Brunei Darussalam, Cambodia, Myanmar, Laos, and Vietnam. Those five countries did not join ASEAN simultaneously, but at different times.

The fourth stage was when the economic crisis of 1997-1998 struck and devastated Southeast Asian economies. After this incident, leaders of Southeast Asian countries began to realize ASEAN's role as a regional organization may involve becoming an economic stabilizer for the region. Following the emergence of this awareness, the fifth stage was the ASEAN Charter, signed as the institutionalization and formalization of the association. After the charter, the organization also agreed to sign its vision for 2020 as a long-term goal as well as a cooperation agreement to establish the ASEAN Community in 2020, which was then advanced to 2015. The sixth stage was the establishment of ASEAN Community in December 2015. The founding of this community marked a new era of the association and a push for a new vision, namely the ASEAN vision 2025. Lastly, the seventh stage is ASEAN integration, which it is still the association's final goal and has yet to be achieved by its leaders.

Currently, ASEAN is still in the sixth stage. Each stage has been marked by the establishment of new institutions in the association. Furthermore, each year 
cooperation with other countries has also increased. Presently, ASEAN has become a complex organization with a plethora of institutions and with international cooperation with many countries around the world. Adaptive communication in ASEAN, however, is still not effective, as seen from the fact that the association has yet to be able to adjust to the dynamics of rapid development. Processing information effectively via websites or a dynamic medium to coordinate member states in responding to ongoing phenomena must still be done continuously. Knowledge transfer is crucial to the open system function of the adaptive organizational system. To be able to maintain its existence, the ASEAN Secretariat must be able to conduct effective knowledge transfer as feedback for the environment, which in turn will encourage future input for the organization.

\section{Conclusion}

The ASEAN Secretariat is an organizational structure that is able to represent the level of development and maturity of the organization. From field observations and interviews, adaptive communication in ASEAN has not optimally met the autopoietic and self-referential context outlined by Luhmann's systems theory. The key concepts of autopoiesis, differentiation, and reduction of complexity are the basis of measurement and assessment of this system. It can be said that the association has not had effective capability in any of these. ASEAN has indeed grown, evolved and adapted to the environment. However, it cannot be said to be optimal in conducting differentiation and self-reference related to its own needs. The organization must still improve its systems and mechanisms. In the future, ASEAN must continue developing the process of enactment or creation of its environment, the process of selection or information sorting, and retention or organizational memory development as a guide to making organizational decisions. This must be further developed to demonstrate ASEAN's ability to adapt to its environment and the complex challenges it faces.

\section{References}

ASEAN Secretariat. (2016). ASEAN Document Series 2015. Jakarta: ASEAN Secretariat. . (2015). ASEAN Annual Report 2014-2015: Our People, Our Community, Our

Vision. Jakarta: ASEAN Secretariat. . (2015). ASEAN Document Series 2014. Jakarta: ASEAN Secretariat. 
. (2015). ASEAN 2025: Forging Ahead Together. Jakarta: ASEAN Secretariat.

. (2014). ASEAN Annual Report 2013-2014. Jakarta: ASEAN Secretariat.

. (2014). ASEAN Document Series 2013. Jakarta: ASEAN Secretariat.

. (2013). ASEAN Annual Report 2012-2013. Jakarta: ASEAN Secretariat.

. (2011). ASEAN Document Series 2009. Jakarta: ASEAN Secretariat

. (2009). ASEAN Document Series 2008. Jakarta: ASEAN Secretariat.

. (2009). Roadmap for an ASEAN Community 2009-2015. Jakarta: ASEAN

Secretariat.

. (2009). The ASEAN Charter. Jakarta: ASEAN Secretariat.

. (2008). ASEAN Document Series 2007. Jakarta: ASEAN Secretariat.

. (2007). ASEAN Document Series 2006. Jakarta: ASEAN Secretariat.

. (2006). ASEAN Document Series 2005. Jakarta: ASEAN Secretariat.

. (2006). Handbook of Selected ASEAN Political Documents. 3rd Edition. Jakarta:

ASEAN Secretariat.

. (2005). ASEAN Document Series 2004. Jakarta: ASEAN Secretariat.

. (1978). 10 Years ASEAN. Jakarta: ASEAN Secretariat.

(n.d.). ASEAN Organisation Structure. Retrieved from

http://www.asean.org/asean/asean-structure/organisational-structure-2/

(n.d.). ASEAN Structure. Retrieved from

http://www.asean.org/asean/asean-structure/

Asian Development Bank Institute. (2014). ASEAN 2030: Toward a Borderless

Economic Community. Tokyo: Asian Development Bank Institute.

Ba, A.D. (2009). (Re)negotiating East and Southeast Asia. California: Stanford University Press.

Caballero-Anthony, M. (2014). Understanding ASEAN's Centrality: Bases and Prospects in an Evolving Regional Architecture. The Pacific Review, 27(4), 563584. doi:10.1080/09512748.2014.924227.

Griffin, E., Ledbetter, A., \& Sparks, G. (2014). A First Look at Communication Theory. 9th Edition. New York: McGraw-Hill.

Indonesian Foreign Ministry. (2008). ASEAN Selayang Pandang. Jakarta: Directorate General for ASEAN Cooperation of Indonesian Foreign Ministry.

Koskinen, K.U. (2013). Knowledge Production in Organization. Switzerland: Springer International Publishing. 
Kraft, H.J.S. (2000). ASEAN and Intra-ASEAN Relations: Weathering the Storm?. The Pacific Review, 13(3), 453-472. doi:10.1080/09512740050147951.

Luhmann, N. (2013). Introduction to System Theory. English Edition. Oxford \& New York: Polity Press.

Luhulima, C.P.F. (2011). Dinamika Asia Tenggara Menuju 2015. Yogyakarta: Pustaka Pelajar. , et al. (2008). Masyarakat Asia Tenggara Menuju Komunitas ASEAN 2015. Yogyakarta: Pustaka Pelajar. et al. (1994). Seperempat Abad ASEAN. Jakarta: ASEAN National Secretary of Indonesian Foreign Ministry.

Miller, K. (2012). Organizational Communication. Boston: Cengage Learning.

Narine, S. (2008). Forty Years of ASEAN: A Historical Review. The Pacific Review, 21(4), 411-429. doi:10.1080/09512740802294689.

Ong, K.Y. (2008). One ASEAN: A Partner for Europe. Asia-Europe Journal, 5(4), 443445. doi:10.1007/s10308-007-0143-1.

Pace, R.W., \& Faules, D.F. (2010). Komunikasi Organisasi. Bandung: Remaja Rosdakarya.

Ramage, M., \& Shipp, K. (2009). System Thinkers. London: Springer-Verlag.

Ritzer, G. (2003). Teori Sosiologi Modern. Yogyakarta: Kencana.

Severino Jr., R.C. (2008). Southeast Asia in Search of an ASEAN Community: Insights from the Former ASEAN Secretary-General. Development in Practice, 18(3), 451453. doi:10.1080/09614520802031159.

Thai Ministry of Foreign Affairs. (2009). ASEAN: Portrait of a Community. Bangkok: ASEAN Affairs Department of Thai Ministry of Foreign Affairs.

Weatherbee, D.E. (2009). International Relations in Southeast Asia: The Struggle for Autonomy. Maryland: Rowman \& Littlefield Publishers.

Wuryandari, G. (Ed.). (2011). Politik Luar Negeri Indonesia di Tengah Arus Perubahan Politik Internasional. Yogyakarta: Pustaka Pelajar.

Yin, R.K. (2009). Case Study Research: Design and Methods. $4^{\text {th }}$ edition. London, New Dehli \& Singapore: Sage Publication. 